\title{
La muerte simbólica. El cuadro con la representación de Silencio y Monja crucificada del Beaterio del Carmen de San Blas en Cusco ${ }^{1}$
}

\author{
Ewa Kubiak \\ Instituto de Historia del Arte, Universidad de Łódź, Polonia \\ Instituto Polaco de Investigación de Arte Mundial \\ Juan Gómez Huacso \\ Universidad Nacional Mayor de San Marcos, Lima, Perú
}

\section{El CUADRo: SiLENCIO / Monja CRUCIFICADA}

En el antiguo Beaterio de San Blas en Cusco, actualmente dirigido por las Carmelitas Misioneras, se encuentra un cuadro fascinante debido a la singularidad de su iconografía y la funcionalidad que tuvo en el claustro al que pertenece.

${ }^{1}$ En el presente artículo se usa dos nombres del beaterio que aparecen en los documentos históricos: Beaterio de San Blas y Beaterio del Carmen. En este lugar queríamos agradecer a tres personas sin quienes no sería posible preparar este artículo. La primera es la hermana Mariveld Bravo Béjar, a quien agradecemos mucho por su apoyo en obtener el permiso para poder realizar las fotografías del cuadro que pertenece al antiguo beaterio y por su interés enorme en el desarrollo de las investigaciones sobre la historia y el arte del Beaterio del Carmen. Queremos agradecer también a Donato Amado Gonzales, quien nos anima a continuar con los estudios cusqueños y apoya en la búsqueda de los documentos en los archivos. De la parte de coautora la preparación de este artículo fuera tampoco imposible sin un apoyo de la Universidad de Varsovia. Las investigaciones de Ewa Kubiak sobre el arte colonial cusqueño están siendo realizadas gracias a las estancias disfrutadas en El Centro de Estudios Andinos de la Universidad de Varsovia en el Cusco (CEAC UV). Quiero agradecer al profesor Mariusz Ziółkowski por la posibilidad de continuar con estos estudios. 
Se trata de una pintura de doble cara donde se representan una alegoría sobre el silencio monástico y la renuncia de la vida secular y mundana, tomando como protagonista la figura de una monja con atributos que simbolizan las reglas de conducta para una correcta vida monástica y de consagración hacia Dios. Las cualidades estilísticas que presentan ambas imágenes nos llevan a pensar que posiblemente fue realizado a principios del siglo XIX. Para nuestro análisis hemos titulado estas dos representaciones como Silencio y Monja crucificada.

\section{SILENCIO}

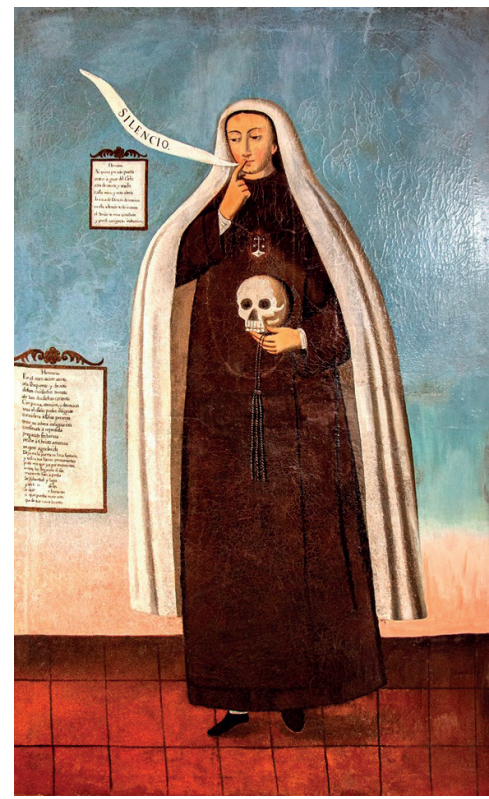

Fig. 1. Silencio, anverso de la pintura del Beaterio de San Blas, Cusco, principios del s. XIX, anónimo.

Es una obra de formato rectangular donde podemos ver a una monja de pie pintada de cuerpo entero en un espacio con fondo celeste y plataforma cuadriculada [fig. 1], lleva un hábito de color marrón, un escapulario con el escudo de la orden de las carmelitas descalzas sobre el pecho y una toca o velo blanco que se extiende hasta la altura de sus piernas. Con la mano izquierda sostiene un cráneo y un látigo de tres colas, y con la derecha, ubicada a la altura del rostro, posa el dedo índice sobre sus labios haciendo un gesto de silencio que se hace explícito mediante la filacteria contigua y una pequeña cartela donde 
advierte: Hermana. Si quieres por esta puerta entrar à gosar del Cielo con devoción, y reselo calla mira, y esta alerta la casa de Dios, es de oración en ella silencio todo instante el Señor te mira constante y puede castigar, tu indevoción. (Apéndice I)

\section{LA MONJA CRUCIFICADA}

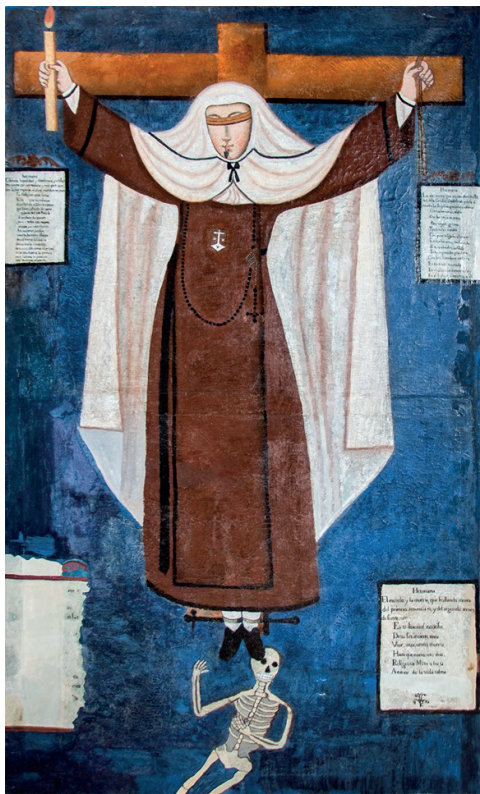

Fig. 2. Monja crucificada, reverso de la pintura del Beaterio de San Blas, Cusco, principios del siglo XIX, anónimo.

En el reverso [fig. 2], sobre un fondo completamente azul, una monja con el hábito carmelitano está atada sobre una cruz con los brazos extendidos y las piernas juntas; al igual que el primero, viste hábito marrón y una toca blanca, pero también un manto cuelga sobre sus hombros y cubre parcialmente su pecho y bajo este, carga un rosario que rodea el escudo carmelita dibujado sobre el escapulario.

El significado de sus atributos se explica en las cuatro cartelas que se distribuyen en los extremos laterales del cuadro (Apéndice II), lamentablemente una de ellas con el texto totalmente deteriorado. La mano derecha sostiene un cirio encendido y la izquierda deja colgar un látigo de tres colas, símbolos de la caridad y la penitencia respectivamente; tiene los ojos vendados y la boca 
sellada con una cerradura: Cilencio, humildad y obediencia, publica mis lavios con serradura y mis ojos que ven[d] ados reparas, el alma mantienen pura, y en la parte inferior, bajo los pies de la monja, yace un esqueleto como expresión del dominio sobre la muerte y lo mundano: El mundo y la muerte, que hollando meves del primero renuncia es, y del segundo recuerdo fuerte.

\section{El CONTEXTo de ubicación de la obra: BeATERIo de SAN Blas}

Durante la época colonial los beaterios funcionaron como instituciones basadas en la tradición de la vida monástica europea. Desde la Edad Media, junto a los grandes monasterios, se constituyeron lugares de "recogimiento" de carácter semiformal que funcionaban de acuerdo con las reglas de la orden religiosa al que correspondían. San Francisco, como el primero, introdujo en 1212 una forma de la vida medio monástica para los seglares, creó la comunidad de la tercera orden para los laicos, quienes no podían abandonar su vida familiar, pero querían cumplir los elementos principales de la enseñanza de los franciscanos. Después otras órdenes religiosas facilitaron este tipo de vida para los laicos: dominicos (1406), agustinos (1409), servitas (1424), carmelitas (1452), mínimos (1508), trinitarios y premostratenses (1751). Las comunidades de esta tercera orden eran denominadas como terciarios y "su principal característica es la búsqueda de la perfección cristiana bajo la dependencia de una orden a la que jurídicamente están subordinados y de la cual reciben la orientación espiritual."²

Los beaterios fueron lugares de recogimiento voluntario destinado exclusivamente para las mujeres y su funcionamiento no requería la aprobación oficial de la Iglesia, siendo en algunos casos suficiente el apoyo de autoridades locales para su constitución. Según el Diccionario de la lengua castellana de 1726, "beaterio" eran "La casa ò lugar donde viven la[s] Beatas que forman comunidad, y tienen regla. Lat. Piarum foeminarium domùs, vel ascetarium."’, a diferencia de los conventos, estos se caracterizaron por su distinto grado de formalidad, las beatas adoptaban una forma de vida parecida a las monjas, pero en la mayoría de los casos no vivían bajo votos solemnes, aunque sí bajo el voto simple o privado. ${ }^{4}$ Podían usar hábitos y vivir juntas en un beaterio o residir en su propia casa. Esto se explica perfectamente en la definición de "beata" que encontramos en el mismo diccionario:

\footnotetext{
2 Pi CoRrales 1988: 255.

3 Diccionario 1726: 583.

${ }^{4}$ Burns 2002: 87.
} 
Muger que viste hábito Religioso y professa celibato, y vive con recogimiento, ocupándose en oración y obras de charidád, y siguiendo la regla que mas se acomóda à su génio, aunque no en Comunidad. En algunas partes, como en Madrid, en la Casa que llaman de San Joseph, no solo viven estas Beátas en Comunidád, sino tambien guardan clausura. En otras aunque viven en Comunidad no la guardan: como en Alcalá. Llámanse Beátas por ampliación del Latino Beatus, a, um. Lat. Pia foemina, religioso habitu studioque erga Deum vitam sancti ad devote exigens. $[\ldots]^{5}$

Esta institución fue muy importante en la vida social a lo largo del periodo colonial, pues acogía a mujeres solitarias y de bajos recursos económicos que quisiesen dedicar su vida al servicio de Dios, en ese sentido, Ignacio de Castro en su Relación de Cusco (1788), al referirse a los beaterios de esta ciudad, plantea una definición más amplia al considerarlas como lugares donde "se recogen aquellas pobres, que ó por su calidad ó por su escasez de facultades son injustamente excluidas de los Monasterios y así compensan y satisfacen los deseos de consagrarse a Dios en Religión." 6

Para mediados del siglo XVIII, se presume la existencia de por lo menos diez beaterios en la ciudad del Cusco (en la capital del virreinato funcionaron cinco y en Arequipa tres) ${ }^{7}$, es difícil de calcular un número preciso debido a que en ocasiones estos funcionaban al margen de oficialidad eclesiástica y no tenían una administración estable, en su mayoría eran muy pobres, funcionaron en medio de constantes interrupciones, desaparecieron paulatinamente y se fundaron sobre ellos nuevas instituciones; en cambio, "recogimientos" como el de las Nazarenas, del Carmen de San Blas o de Santa Rosa están muy bien definidos en el espacio urbano y social, teniendo la ubicación de sus capillas y el financiamiento más o menos fijo.

Hasta el momento no se conoce la fecha exacta de la fundación del Beaterio del Carmen de San Blas, las referencia documental más antigua que se tiene sobre este claustro la encontramos en el informe que realizó el párroco de San Blas al obispo Manuel de Mollinedo y Angulo en $1689,{ }^{8}$ pero esta investigación nos permitió ubicar un documento más temprano ${ }^{9}$, se trata de un contrato de compra del terreno sobre el que se edificó el beaterio carmelita, lo que nos permite suponer que este se podría haber constituido entre los años 1675 y 1680. Este documento contiene información sobre la venta del "ssolar que viene asaer

5 Diccionario 1726: 582-583; la recopilación de las entradas de los antiguos diccionarios nos ofrece: BraguIER 2019: 53-55.

${ }^{6}$ Castro 1978 [1788]: 54.

7 Cantuarias Vargas 2002: 65.

${ }^{8}$ Cuzco 16891982 [1689]: 233.

9 Por la ayuda en la búsqueda y localización de este documento la coautora de este artículo querría agradecer a Donato Amado Gonzales. 
Cerca de la Plassela de la Parrioquia de señor Samblas de esta d[ic]ha ciudad donde esta un sitio nombrado la Magdalena" por Francisco de Madera e Isabel Fernangil de Cabrera. El terreno fue comprado por la madre Leonarda de la Soledad "beata que a bivido y bive congregada Con otrras del mesmo Digtamen en el beaterio y adbocación de Nuestra Señora del Carmen que esta presente". ${ }^{10}$ Documentos posteriores confirman la compra del terreno para el beaterio del Carmen por la madre Leonarda de la Soledad. ${ }^{11}$

En el último tercio del siglo XVIII, bajo la dirección de la prepósita María Nicolasa de Christo, el beaterio de San Blas alcanzó su mayor desarrollo administrativo. Gracias a sus esfuerzos no solo se salvó el funcionamiento del beaterio ${ }^{12}$ sino que también se amplió el terreno donde funcionaba, ${ }^{13}$ se reformó la arquitectura y enriqueció la decoración de su capilla. ${ }^{14}$

Los beaterios cusqueños por lo general no tuvieron mucho apoyo económico, el "recogimiento" de San Blas a pesar de que tuvo, después de las Nazarenas, la mejor solvencia económica de entre los beaterios de la ciudad, se sabe que en 1826 la prepósita madre Francisca del Sacramento se quejaba por la situación material precaria por la que atravesaban. En aquel momento su funcionamiento dependía de las rentas de cuatro haciendas: Ayupata (ubicado en la parroquia de San Sebastián), Lauramarca, Huayronca y Salla Bella; del arriendo de tres casas y algunos "topos de tierras". ${ }^{15}$ La simpleza de los edificios donde funcionaban estos beaterios refleja esa precariedad económica, donde la sencillez del claustro y capilla (o iglesia) es una característica recurrente en su estructura arquitectónica.

${ }^{10}$ ARC (Archivo Regional del Cusco), Sección Notarial, escribano Flores Bastidas Juan, 1675-1680, ff. 133v. $-135 \mathrm{r}$.

${ }^{11}$ La compra fue realizada con el apoyo de Don Juan de Medina. Esta información la encontramos en el testamento de otra beata, la madre Juana de San Pedro de 1720. ARC, Sección Notarial, escribano Matias Ximenez Ortega, 1720, ff. 345 r. - 347 v. y también en el documento de 1772, una demanda de María Nicolasa de Christo, Preposita del Beaterio de Nuestra Señora del Carmen; AAC (Archivo Arzobispal del Cusco, Época colonial, Órdenes religiosas, Signatura XLIV, 3, 44, ff. 20.

12 AAC, Época colonial, Órdenes religiosas, Signatura XLIV, 3, 44, ff. 20.

13 AAC, Época colonial, Órdenes religiosas, Signatura C6, 3, 41, ff. 9; ACC, Época colonial, Órdenes religiosas, Signatura C54, 1, 19, ff. 4.

${ }^{14}$ AAC, Época colonial, Órdenes religiosas, Signatura XLIV, 3, 44, ff. 20; AAC, Época colonial, Bienes, Signatura C8, 1, 9, ff. 10; ARC, Melchor Ayesta, 48(45), 1789-1791, ff. 121 v.-123 v. El último documento conocemos gracias a la historiadora Milena Manotupa Gómez. Coautora de este artículo Ewa Kubiak y Milena Manotupa Gómez están actualmente preparando el libro más amplio sobre el Beaterio de San Blas, es un análisis histórico-artístico, con la recopilación de los documentos que tratan de esta institución. Véase también: KuBIAK 2020.

15 AAC, Época Colonial, Visitas, Signatura C17, 4, 66, ff.3r.-3 v., 6 r. 
Gracias a una fotografía antigua de la primera mitad del siglo $\mathrm{XX}^{16}$ logramos identificar la ubicación original de la pintura [fig. 3], lo que constituye el tema principal de nuestro análisis. En la foto se puede observar el segundo piso del claustro, en el fondo del pasadizo, cruzando la espadaña, un grupo de beatas sube por una escalera que las conduce a la puerta pintada con la imagen de la monja del Silencio. Posterior al terremoto que destruyó la ciudad, una fotografía del año 1958, nos muestra el mismo lugar desde otra perspectiva, lamentablemente para este momento ya no se encuentra la puerta pintada. [fig. 4], el espacio interior al que daba acceso esta destruido y ya no está la escalera por donde subían las beatas en la primera foto. Gracias a la entrevista con la hermana de la congregación actual de las Carmelitas Misioneras, Dolores (Rosario) Huillca Usucachi, quien fue beata desde antes de la reforma de la institución en el año 1963, conocemos la disposición espacial y funcional del edificio antes de sufrir transformaciones realizadas en la década de los sesenta, por ello sabemos que la ubicación de la puerta pintada daba acceso al noviciado, ${ }^{17}$ lo cual permite interpretar el cuadro como medio de instrucción para las novicias cuyo contenido es un recordatorio de las reglas y los votos para quienes permanecían dentro del beaterio carmelitano.
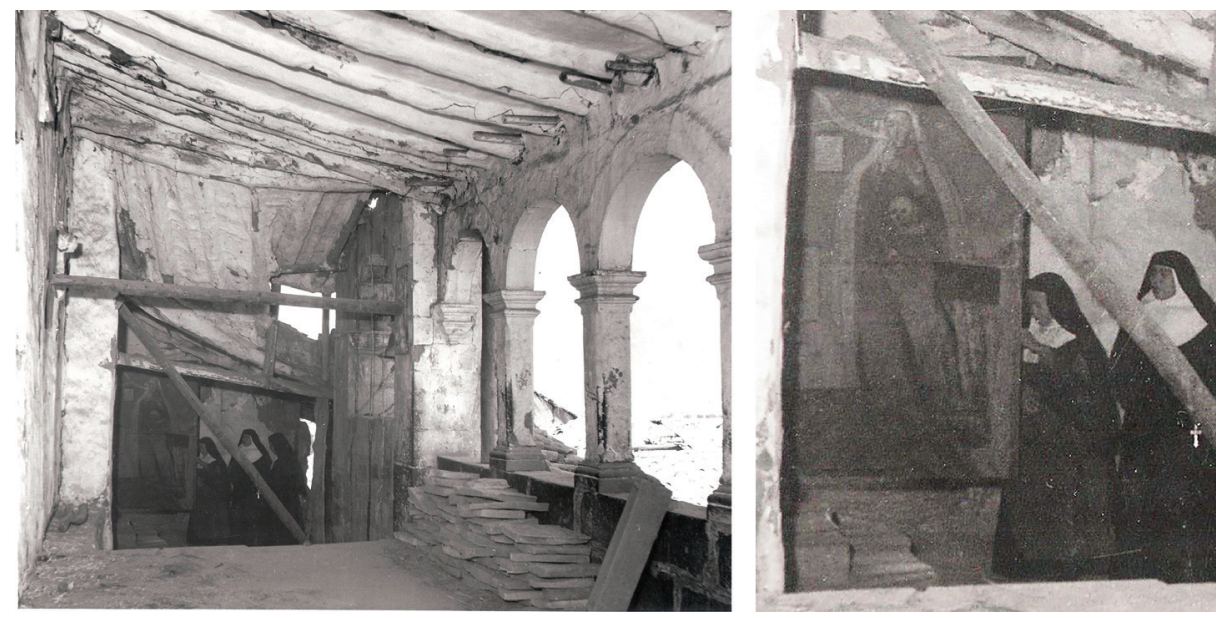

Fig. 3. El segundo nivel del claustro del Beaterio de San Blas, fotografía anónima, la primera mitad del siglo XX, colección particular de Luis Nieto Degregori.

${ }^{16}$ Otra vez queremos agradecer por pasarnos esta fotografía a Milena Manotupa Gomez.

17 En 1963 terminó el funcionamiento de la Agregación del Beaterio del Carmen de San Blas que fue convertido en la Congregación de las Carmelitas Misioneras. Esta transformación tuvo lugar durante la época del arzobispo Carlos María Jurgens Byrne (1956-1965). Por estas informaciones agradecemos a la hermana Mariveld Bravo Béjar. 


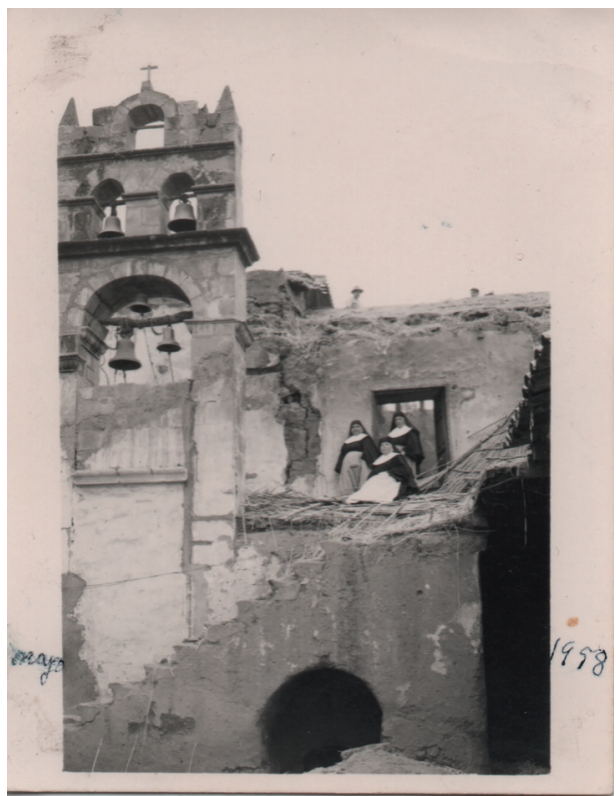

Fig. 4. El segundo nivel del claustro del Beaterio de San Blas, fotografía anónima, mayo 1958, Archivo Fotográfico, Carmelitas Misioneras, Perú, Agregación del Beaterio San Blas.

\section{ICONOGRAFÍA DEL CUADRO}

La iconografía de este cuadro, aunque no fue muy popular, aparece en imágenes religiosas desde la edad media, en nuestro caso podemos tratar a estas imágenes como la manifestación de los ideales de la vida monástica. Las beatas de San Blas no formaron un monasterio, pero llevaron la vida monacal según la regla carmelitana, las hermanas usaban hábitos, su categoría jerárquica se distinguía por el color de su velo, el blanco era usado por las novicias y el negro por las hermanas que vivían supeditadas al voto, ${ }^{18}$ aquello se mantuvo hasta los últimos años de funcionamiento del beaterio, como podemos observar en una

${ }^{18}$ Los hábitos de las beatas y los hermanos terceros carmelitas están descritos en el Manual de las Beatas y Hermanos terceros, de la horden de la siempre Virgen, y Madre de Dios, Sancta María del monte Carmelo de Diego Martínez de Coria Maldonado (1592: 122 v. - 123 r.); "Los vestidos de nuestros religiosos sean de lana uniformes, las túnicas sean de burel tirantes a negras, sean redondas que lleguen hasta los cobillos y sean más anchas q[ue] estrechas. No vayan pespuntadas en ninguna parte. Tendrán también un escapulario [...]. Sean ceñidas con cintas de cuero negro sobre la túnica, la que será de ancho de dos dedos, y no sera de otro artificioso color $[\ldots] "$. 
foto del 1962, donde se distingue el uso de dos tipos de velos. [fig. 5]. Esto confirma la localización de la pintura como puerta de entrada al noviciado, ya que sus figuras son presentadas tal y como vestían las novicias.

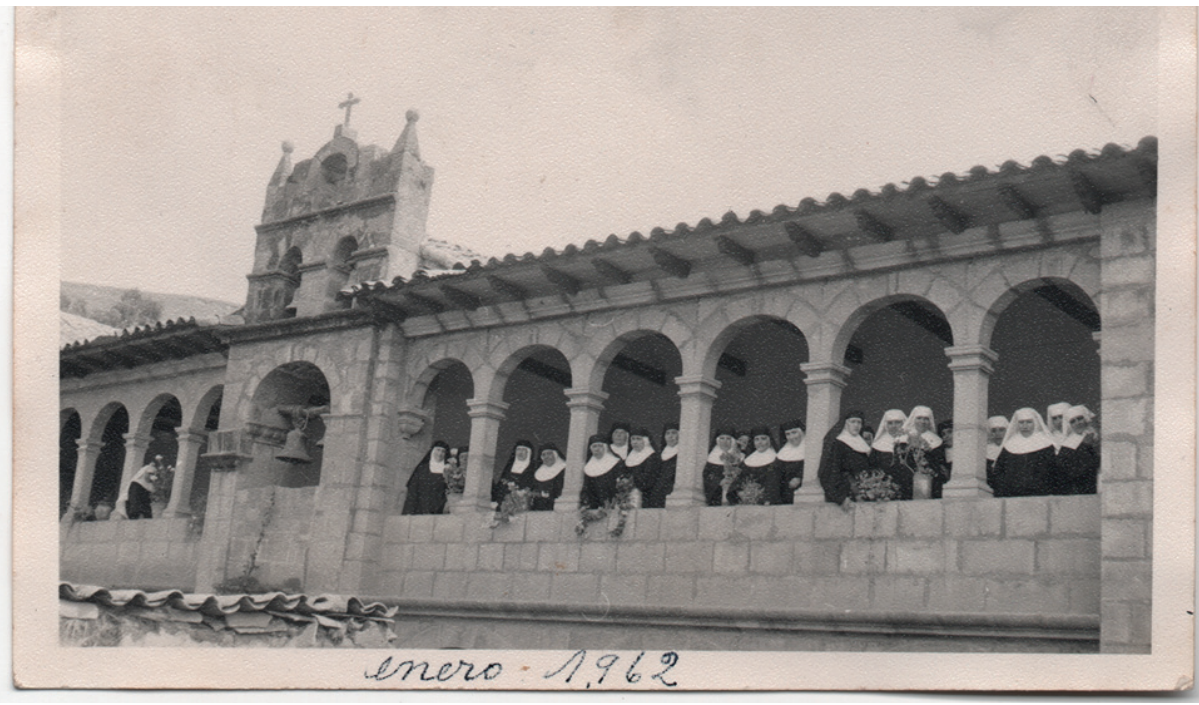

Fig. 5. El segundo nivel del claustro del Beaterio de San Blas después de la transformación, fotografía anónima, enero 1962, Archivo Fotográfico, Carmelitas Misioneras, Perú, Agregación del Beaterio San Blas.

La primera imagen de esta puerta representa la alegoría del Silencio, que podemos definir como la primera regla en la vida de un beaterio clausurado. En el Emblematum libellus de 1531, Andrea Alciato propone la alegoría del silencio representada por un hombre que coloca el dedo sobre sus labios, la imagen que mostramos en este artículo es de la edición de 1564 [fig. 6], la inscripción que lo acompaña hace alusión a la divinidad egipcia Harpócrates, hijo de Isis y Osiris, reconocido como el dios del Silencio. Santiago Sebastián considera que el silencio es esencialmente una virtud religiosa y su importancia parece clara en la vida monástica. ${ }^{19}$ Esta alegoría apareció también en otros libros de emblemas, como por ejemplo en el tratado de Sebastián de Covarrubias Orozco (1610) o en el libro de Juan de Horozco y Covarrubias (1592), ambos titulados Emblemas morales. ${ }^{20}$ [fig. 7]

\footnotetext{
19 Sebastián 1993 [1985]: 41-42.

20 Vistarini, Cull 1999: 388, 439; Covarrubias Horozco 1610: 226; Horozco y CovaRRUBIAS 1591: 73.
} 


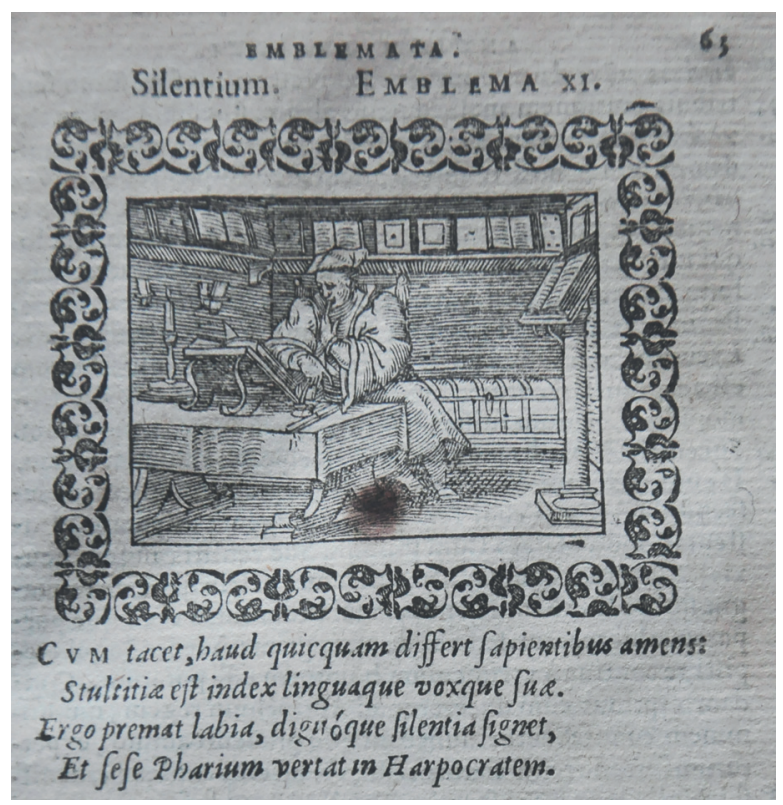

Fig. 6. Silentium, Emblema 11, Andrea Alciati (1564: 63).
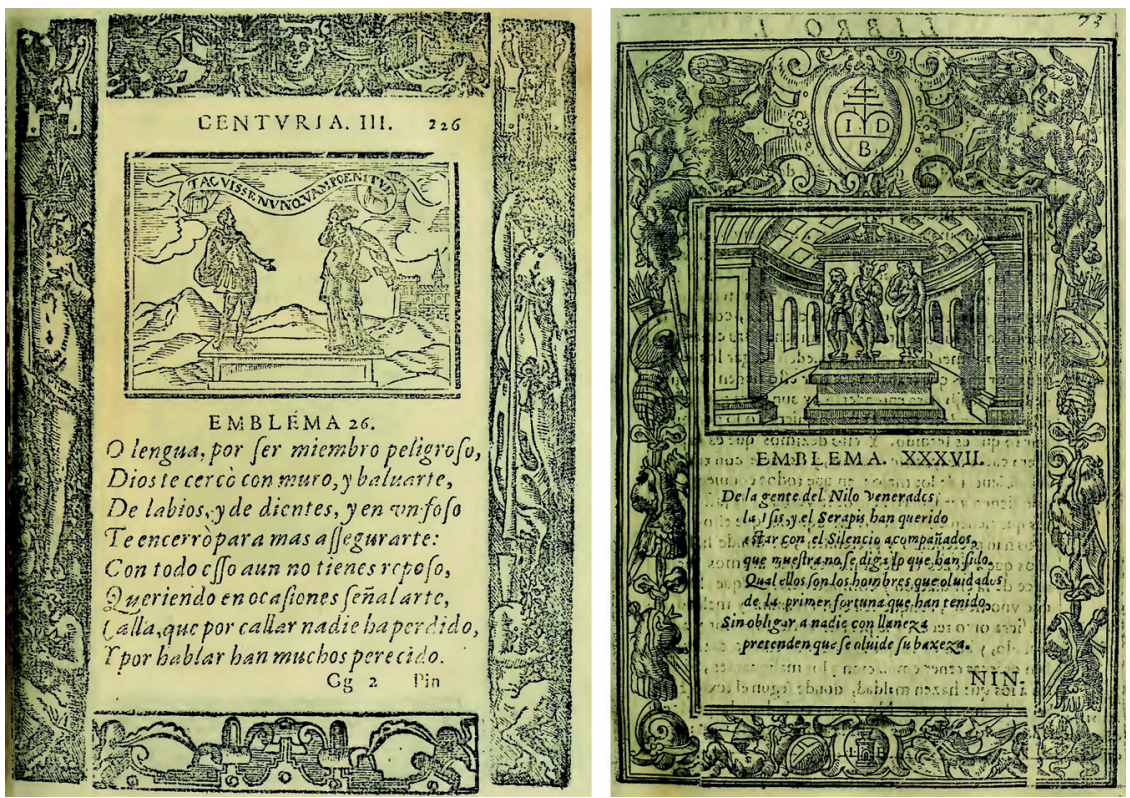

Fig. 7. Embléma 26, Sebastián de Covarrubias Orozco (1610: 226) y Emblema XXXVII, Juan de Horozco y Covarrubias (1592: 73). 
Como fuente de inspiración para representar el silencio también sirvieron la descripción y las imágenes de las diferentes ediciones del libro de Iconología de Cesare Ripa. Este autor describió el silencio como "huomo Vecchio, il quale si tenga un dito alle labbra della boca". ${ }^{21}$ Las imágenes basadas en esta descripción se encuentran en las decoraciones de las bóvedas pintadas por Manuel Bayeu y Subias (1784-1787) en la iglesia y el claustro de La Cartuja de Nuestra Señora de las Fuentes en Sariñena de Aragón en España [fig. 8], esta figura forma parte de un programa iconográfico más amplio que, junto con otras imágenes alegóricas, muestran la vida perfecta de un monje cartujano, especialmente "quince alegorías que recorren las bóvedas del claustro de capillas, parece que pretenden compendiar todas aquellas que el buen cartujo puede observar para alcanzar una perfecta vida virtuosa, con arreglo a las existencias de su religión." ${ }^{22} \mathrm{El}$ anciano que representa el silencio muestra el gesto típico con el dedo en los labios y en la mano agarra un ramo de albérchigo que es una alusión a Harpocrátes, por el árbol que según la tradición le fue consagrado.

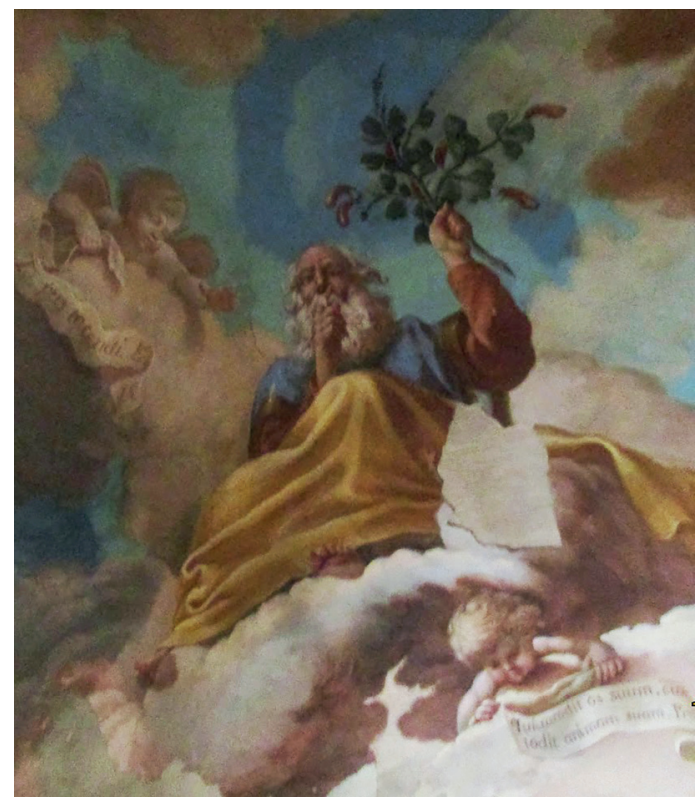

Fig. 8. Manuel Bayeu y Subias, Silencio, pintura mural (1784-1787), iglesia de La Cartuja de Nuestra Señora de las Fuentes, Sariñena, Aragón, España.

${ }^{21}$ RIPA 1645: 570; La primera edición de Iconología de Cesare Ripa tenía lugar el 1593, pero que el libro sin ilustraciones. La primera edición donde al texto acompañaron las imágenes fue publicado en 1603.

${ }^{22}$ Barlés, Calvo Ruata 2001: 27-28. 
Un lienzo con mayor parecido a la monja del beaterio carmelita es el de un fraile franciscano pintado en el siglo XVII que se conserva en el convento de San Francisco de Querétaro en México. Como lo describe Nuria Salazar Simarro "el fraile está de pie sobre el globo terráqueo, en la mano derecha sostiene las disciplinas y en la izquierda, una larga candela encendida. Un candado en la boca destaca también la importancia del silencio que da nombre a la obra", ${ }^{23}$ a la derecha se encuentran tres libros apilados sobre el suelo y a la izquierda una mesa sobre la que reposa un cráneo y un reloj de arena, el cual simboliza el paso del tiempo [fig. 9].

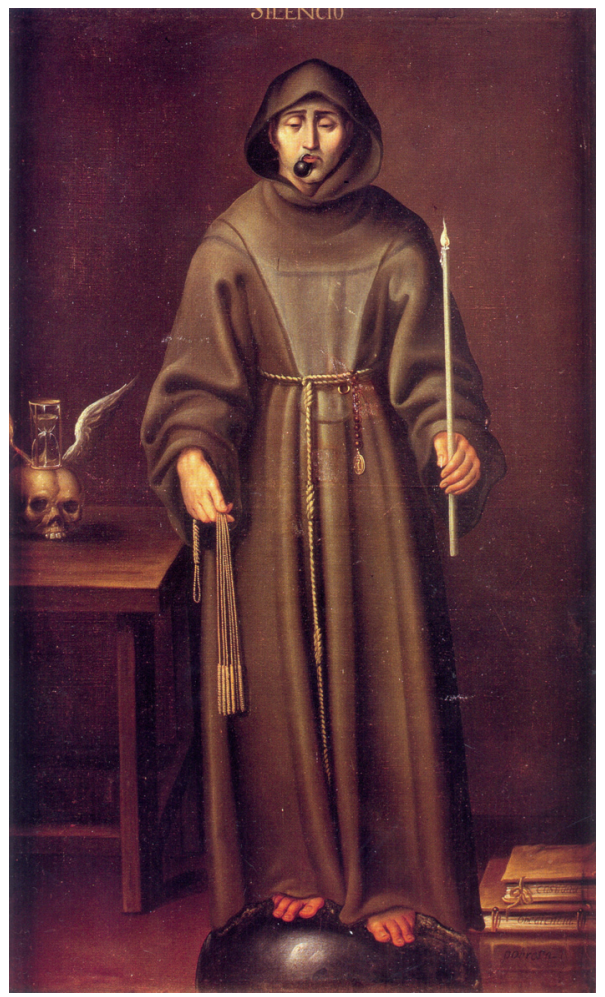

Fig. 9. Silencio, anónimo, el siglo XVII, Museo Regional de Querétaro, INAH.

La segunda imagen, con la representación de la Monja Crucificada, constituye un motivo mucho más popular, especialmente en las decoraciones de conventos y la producción artística que se encuentran en los monasterios. El primer texto importante sobre esta iconografía fue publicado en 1973 por Gabriel Llompart, donde se analiza el fresco de la religiosa crucificada de las

${ }^{23}$ Salazar Simarro 2011: 138. 
Descalzas Reales de Madrid [fig. 12] como parte de la tradición religiosa de asimilar una actitud y forma de vida que imite a la de Cristo. De los textos que acompañan a la imagen, la frase principal es una cita de la epístola de San $\mathrm{Pa}$ blo a los Gálatas: "Estoy concrucificado con Cristo" (Gal, 2, 20), fragmento de una frase más larga que concluye: "y si vivo, no soy yo que vivo, sino Cristo que vive en mí". ${ }^{24}$ Llompart destaca también diferentes grabados con representaciones parecidas.

A mediados de la década noventa, la historiadora Almuth Seebohn publicó un artículo sobre la imagen del monje crucificado, presentando un amplio panorama del desarrollo de esta iconografía desde la edad media hasta principios del siglo XIX ${ }^{25}$ El último artículo sobre este tema fue publicado en el 2017 por Cristina Cruz González, donde analiza la presencia de la piedad femenina en la cultura visual de Nueva España y la relación entre las imágenes de las monjas crucificadas y la vida monástica en los conventos femeninos. La autora repite las imágenes presentadas en el artículo de Seebohn pero añade otras como el Ad Scholastica (c. 1524-62) del manuscrito con el poema sobre la vida monástica de Denis Faucher. [fig. 10] y presenta una de las primeras fuentes grabadas para la representación de la monja crucificada, es un grabado anónimo de 1682 titulado Verdadero retrato de la esposada de la cruz [fig. 11] que repite la composición de Marcos Orozco de 1656. Probablemente estas imágenes sirvieron como modelo para la ya mencionada pintura de Madrid [fig. 12] y el cuadro de Hernández y Gutiérrez del siglo XVII titulado Alegoría del noviciado del Museo Nacional de las Intervenciones en la Ciudad de México [fig. 13]. Esta misma autora también destaca otro grabado creado sobre la base de la pintura madrileña, es una composición de Lorenzo de Mansilla titulado Verdadera idea de una Capuchina crucificada, que podemos ver en la página titular del libro sobre las capuchinas en Granada, Compendio histórico chronológico de la fundación maravillosa del Monasterio de Jesús María (1768) de Ángel Thomás ${ }^{26}$ [fig. 14], y repetida posteriormente en el libro La religiosa mortificada. Explicación del cuadro que la presenta con sus inscripciones tomadas de la sagrada escritura á que se añade el manual de del alma religiosa de Manuel de Espinoza, publicado en $1804 .^{27}$

\footnotetext{
24 LlOMPART 1973: 56.

25 SеEвонm 1996: 61-102.

26 Thомás 1768.

${ }^{27}$ EsPinOZA 1804 [1799].
} 


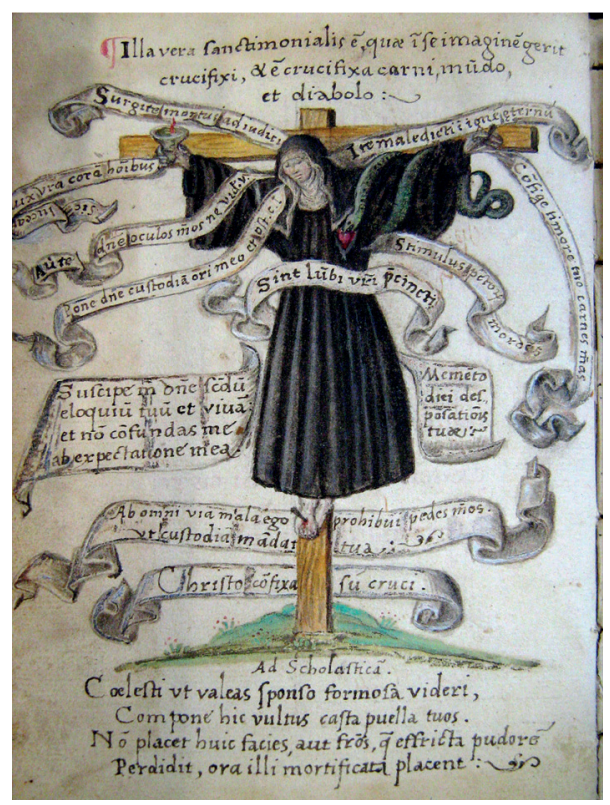

Fig. 10. Ad Scholastica (c. 1524-62), el dibujo del manuscrito con el poema de Denis Faucher, The Kislak Center for Special Collection, University of Pennsylvania, Philadelphia, Manuscrito 1620, f. 1 v.

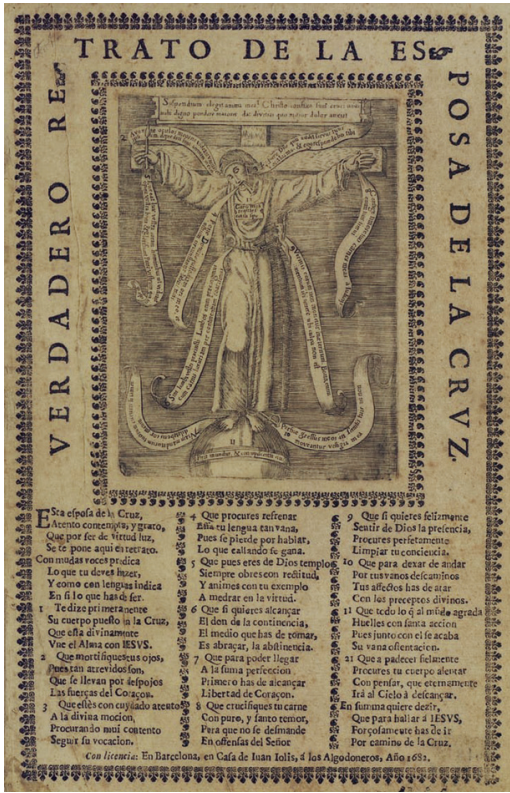

Fig. 11. Verdadero retrato de la esposada de la cruz, Barcelona, 1682. 


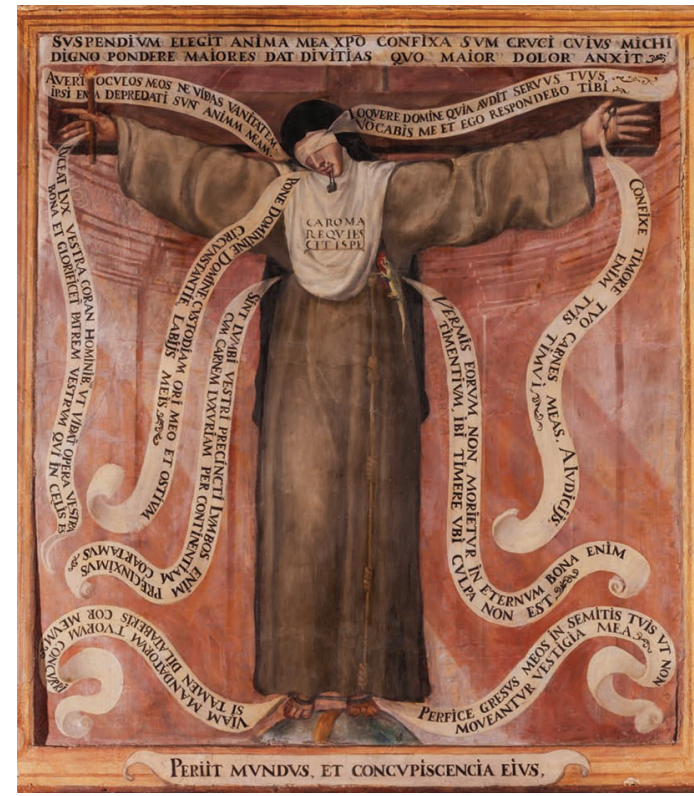

Fig. 12. La monja crucificada, c. 1680, pintura mural, Monasterio de las Dezcalzas Reales, Madrid.

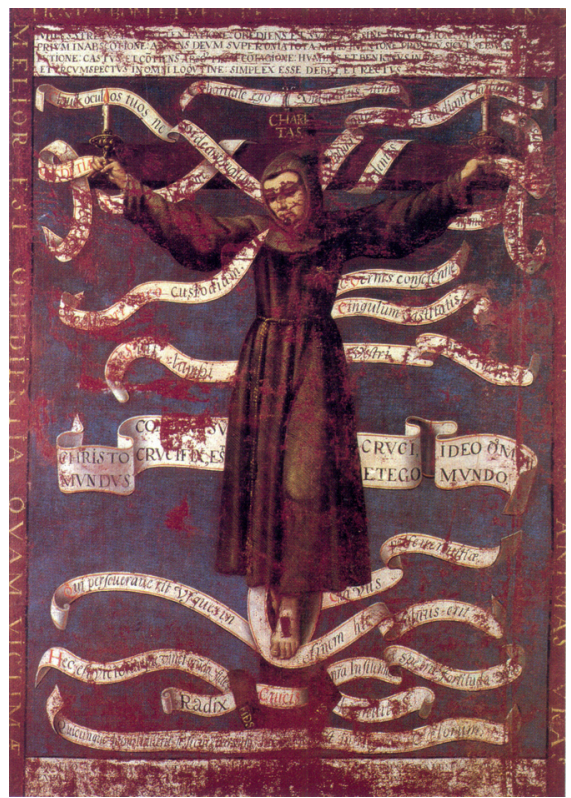

Fig. 13. Hernández y Gutiérrez, Alegoría del noviciado, el siglo XVII, Museo Nacional de las Intervenciones, Ciudad de México. 


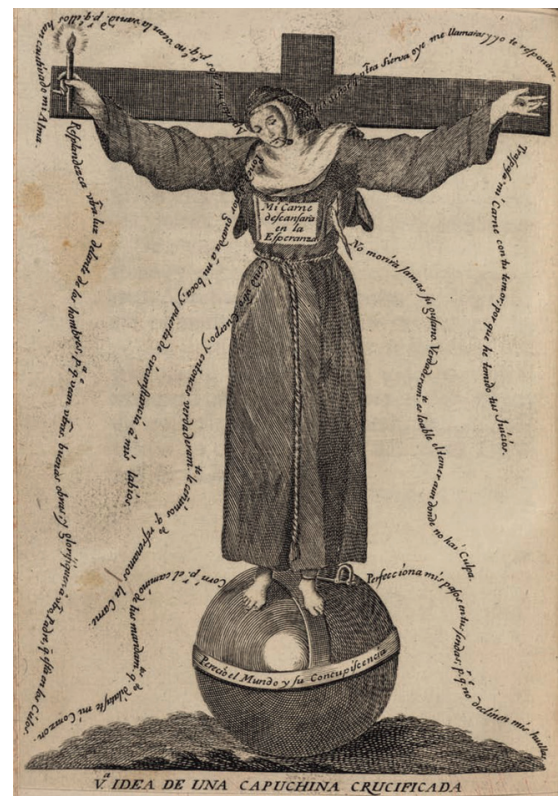

Fig. 14. Lorenzo de Mansilla, Verdadera idea de una Capuchina crucificada, (Thomás 1768).

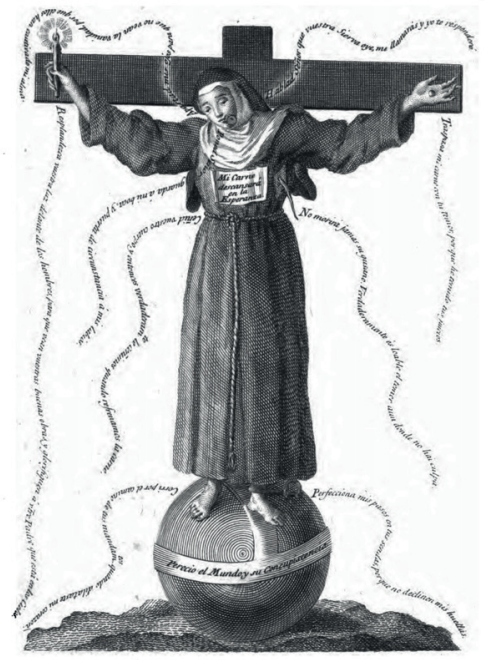

IDEA DE UNA RELIGIOSA MORTIFICADA,

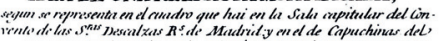
Desiemto de pernitencin de Grrmade.

Fig. 15. Según Lorenzo de Mansilla, Idea de una religiosa mortificada, (Espinoza 1804). 
A este repertorio de imágenes se puede adjuntar también cuadros ubicados en Polonia y América del Sur, sobre las composiciones polacas la historiadora Krystyna Moisan Jabłońska describe las pinturas del monasterio de las clarisas [fig. 16] y carmelitas en Cracovia, de las benedictinas en Staniątki y de la iglesia de Señor Jesús en Poznań: ${ }^{28}$ también describe las imágenes con representaciones masculinas y muestra las fuentes grabadas analizando la relación entre las composiciones plásticas y el pensamiento de la época, destaca los sermones y otras fuentes literarias que permitieron la creación de estas pinturas.

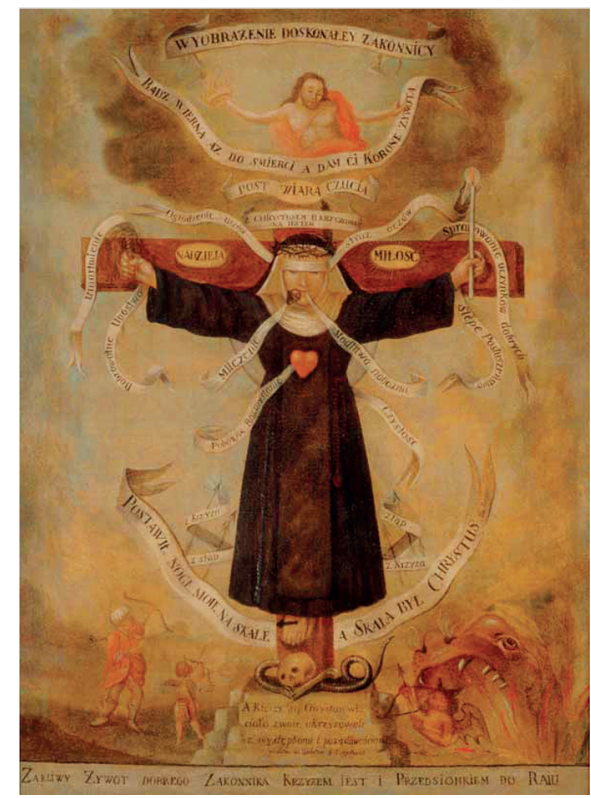

Fig. 16. Imagen de la monja perfecta, anónimo, el final del siglo XVIII, Convento de las clarisas, Cracovia.

Gracias al texto de Ángel Peña Martín hemos conocido otra representación de la Religiosa mortificada en el territorio de América del Sur, es un cuadro anónimo del siglo XVIII que se encuentra en la Sala de Profundis del Monasterio de la Concepción en Riobamba, en Ecuador [fig. 17]. El autor define está composición como parte de las "representaciones artísticas de carácter alegórico y ejemplarizante que, con un lenguaje simbólico y teológico, mostraban a sus monjas el modelo de conducta a seguir". ${ }^{29}$

${ }^{28}$ MoISON JABŁOŃSKA 2002: 345-354, figs. 280, 281, 283, 288;

${ }^{29}$ PeÑa Martín 2013: 181. 


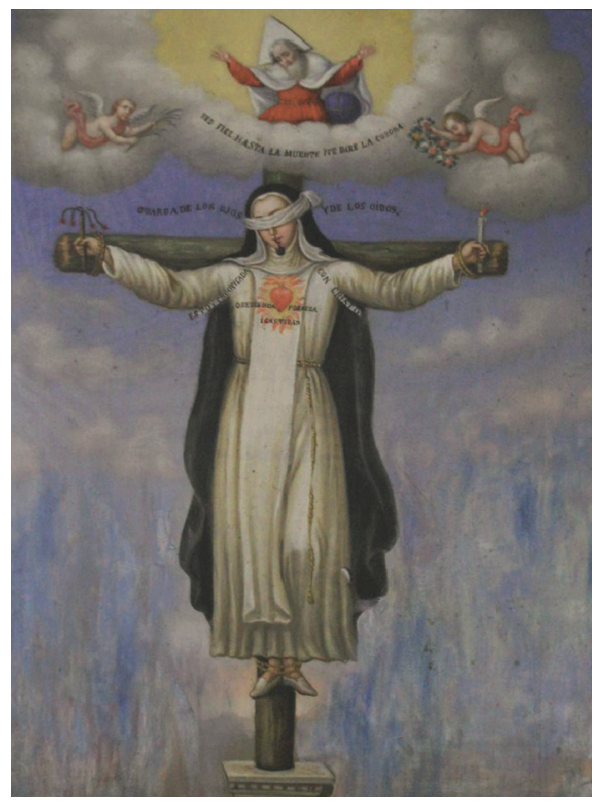

Fig. 17. Religiosa mortificada, anónimo, Sala de Profundis, el Monasterio de la Concepción en Riobamba, Ecuador (fot. Á. Peña Martín).

\section{INSCRIPCIONES}

La mayoría de las inscripciones que acompañan a las imágenes (Apéndice I y II) forman parte de un poema anónimo titulado Espejo de la religiosa perfecta ${ }^{30}$ que podemos encontrar en diferentes libros espirituales de la época. Leonardo Cautinho de Carvalho Rangel cita en su tesis doctoral una estrofa de este poema reproducido en los escritos autobiográficos de carácter místico y ascético titulado Deserto de la carmelita portuguesa Mariana de Purificação (1623-1695). ${ }^{31}$

Este poema, aunque con muchas variaciones, fue difundido en distintas publicaciones de los siglos XVIII y XIX. El libro más temprano que hemos encontrado es La religiosa instruida del franciscano Antonio Arbiol y Díaz (1648-1726), profesor de filosofía y teología, donde escribió tratados espirituales y ascéticos. ${ }^{32}$ El mencionado libro se publicó por primera vez en 1717, la

\footnotetext{
${ }^{30}$ El título puede sufrir algunos pequeños cambios.

31 Cautinho de Carvalho Rangel 2018: 3.

32 COMAdRÁn Ruiz 1961: 81.
} 
segunda en 1753 y después fue reeditado ocho veces más en España durante el resto del siglo XVIII. ${ }^{33}$

Julian de Cos en su estudio sobre Espiritualidad, observancia y liturgia de las monjas dominicas (2014) reproduce el poema Espejo de la religiosidad perfecta ${ }^{34}$ como apéndice del libro La Regla de San Agustín, Constituciones, votos y estado perfección que profesan las Religiosas del Patriarca de Santo Domingo publicado en Valencia en $1720,{ }^{35}$ donde se divulgan las Constituciones de las monjas de la Orden de Predicadores de 1259 pero con las modificaciones realizadas por el fray Antonin Cloche en 1690. ${ }^{36}$ La edición valenciana de estas constituciones sirvió para la formación de las novicias, enfatizando en "los elementos centrales de la espiritualidad de las monjas dominicas del siglo XVIII: los tres votos, la perfección religiosa, la oración mental, el sacramento de la penitencia -y el acompañamiento espiritual- y las indulgencias". ${ }^{37}$
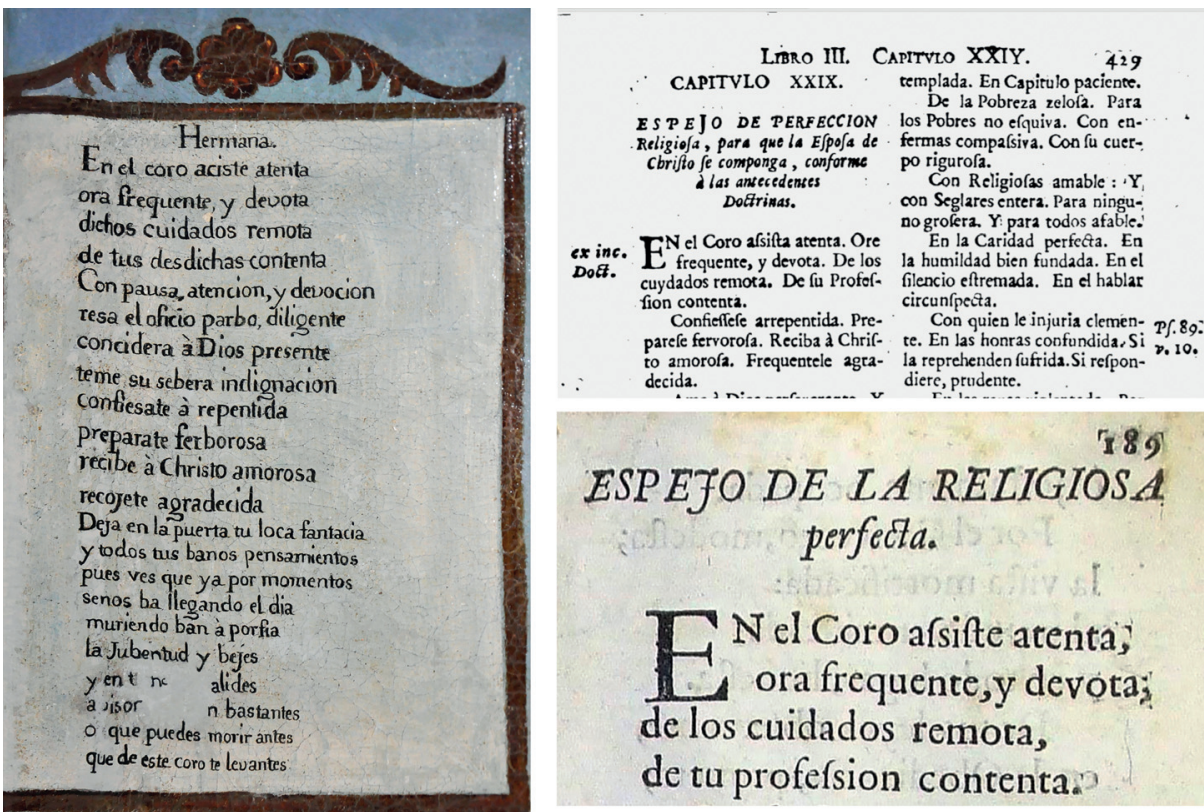

Fig. 18. Fragmento de la inscripción en el cuadro del Beaterio de San Blas, anónimo, los principios del siglo XIX; Las primeras frases del poema, Antonio Arbiol 1717, p. 429; Regla de San Agustín 1720, p. 189.

\footnotetext{
33 Nogar 2018.

${ }^{34}$ Cos 2014: 260-262.

${ }^{35}$ Regla de San Agustín 1720: 189-192.

${ }^{36}$ Cos 2014: 127.

${ }^{37} \operatorname{Cos} 2014: 128$.
} 
También en el libro Nuevo manojito de flores de Buenaventura Tellado (1686-c.1750) se encuentra el poema bajo el título Espejo de perfección Religiosa, para que la Esposa de Christo se componga, conforme, a las antecedentes Doctrinas. El tratado fue publicado por primera vez en Salamanca (1725) y después dos veces en la misma ciudad $(1731,1747)$ y once veces en Madrid $\left(1737,1761,1764\right.$, dos veces en 1766, 1776, 1787, 1794, 1805, 1819, 1860). ${ }^{38}$ Para este estudio hemos consultado la edición madrileña de $1787 .{ }^{39}$

\section{CAPITVLO XXIX. \\ ESPEJO DE PERFECCION Religioja, para que la Espoja de Cbrifto fe componga, conforme \\ d las ansecedenses Doctrimas.}

LmRo III. Caprtiro XXIY.

ex inc. $\mathrm{H}^{\mathrm{N}}$ el Coro afsifta atenta. Ore Dotf. E frequente, y devota. De los cuydados remota. De fu Proferfion contenta.

Confieffere arrepentida. Preparefe fervorofa. Reciba à Chrifto amorofa. Frequentele agradecida.

Ame à Dios perfeverante. $: Y$ firvale diligente. Confiderele prefente. Defeele como amante.

En fanta licion verfada. Viva fiempre compungida. En fu Celda tecogida. O juftamente ocupada.

Prov. Por el Convento modefta.

2.2.2.4 Ia vilta mortificada. Al mundo crucificada. Y en todo lugar hoDefta.

De fus Leyes obfervante. En la obediencia primera. Para los Cargos poltrera. Para las cargas conltante.

Comunique à fu Prelada : Y 2) Confeffor fu fecreto. Trate $d$ todas con refpeto. Mirefe amortajada.

A fu Prelado rendida. Con fu proximo oficiofa : De fus bienes cuydadufa:De fus males condolida.

En la Galud penitente. En lo
adverfo refignada. En Refectorio templada. En Capitulo paciente. De la Pobreza zelofa. Para los Pobres no efquiva. Con enfermas compalsiva. Con fu cuerpo rigurofa.

Con Religiofas amable : ' $Y$ con Seglares entera. Para ninguno grofera. Y: para todos afable.

En la Caridad perfecta. En la humildad bien fundada. En el filencio eftremada. En el hablar circunfpecta.

Con quien le injuria clemen- PS.89:

te. En las honras confundida $S i{ }_{\nu_{0}} 10$.

la reprehenden fufrida. Si refpondiere, prudente.

En las rexas vio!entada. Por obediencia, guftofa. Acuerdere que es Efpola. A Chrifto yà confagrada.

Para los hombres fevera : De fu trato retirada. De Sabios aconfejada. De ignorantes confejera. En fu libertad, cautiva. Y de fu fin cierto cierta. Viva en vida como muerta. Hafta que muerta eftè viva.

Si de Chrifto, y fu confcjo: Sap.7. Quifiere alcançar la palma.Com- $\nu_{0}$ 26. ponga fu cuerpo, y A!ma: A la vilta de efte Elpejo. Amen.

Para el vencimiento de fus paffiones confidere, que: Por breve honra, le le darà eterna deshomra. Por breve deleyte,fe le darà eterno tormento. Por breve gozo, fe le dara eterna pena. Por breve alegria, fe le darà eterua trifteza: Y por breve dencanfo, fe le dara eterno trabajo en el Infierno.

Por el coutrario confidere, que $\sqrt{8}$

Fig. 19. Espejo de perfección Religiosa, Arbiol 1717, p. 429.

\footnotetext{
38 Aguilar Piñal 1995: 34-35.

39 Tellado 1787 [1725].
} 
En el siglo XIX, fuera de las reediciones de los tratados de Antonio Arbiol y Buenaventura Tellado, hemos localizado este poema en las Cartas familiares y algunos otros opúsculos en prosa y verso del Ilustrísimo Sr. D. Fr. Miguel de Santander $(1805)^{40}$ con el título Espejo del Religioso en que se deberá mirar con frecuencia ubicado en las últimas cartas de esta publicación; y también en el libro Regla y Constituciones del Sagrado Orden de Predicadores para las religiosas de coro (1864). ${ }^{41}$

No podemos afirmar la fuente exacta que sirvió de modelo para el pintor del cuadro del Beaterio de San Blas, pues las inscripciones no repiten el poema entero, estas se componen por algunos fragmentos, se cambia el orden de los versos y modifican algunas expresiones, pero mantiene la esencia del mensaje de educación y reafirmación de las beatas y monjas en la vida monástica, siendo un caso excepcional el publicado por Buenaventura Tellado, quien transforma el mensaje hacia el género masculino:

\begin{tabular}{|l|l|}
\hline Inscripción en el cuadro & Buenaventura Tellado 1787 [1725]: 597 \\
\hline $\begin{array}{l}\text { Religiosa [m]osa o vieja } \\
\text { A estrés do la vida calma }\end{array}$ & $\begin{array}{l}\text { Religioso mozo, ó viejo } \\
\text { A este espejo el curso calma; }\end{array}$ \\
\hline
\end{tabular}

\section{A MOdo De CONCLUSión}

Tanto las imágenes de dos caras del cuadro del Beaterio de San Blas, como las inscripciones constituyen un programa iconográfico complejo, la pintura formaba parte de la entrada al noviciado y tenía funciones didácticas que buscaba orientar a las nuevas beatas en el camino de la vida consagrada a Dios. La mayoría de los cuadros con representaciones de las monjas crucificadas se encuentran en los monasterios europeos y americanos, pero el recogimiento de San Blas, aunque era reconocido solamente por las autoridades locales, durante esos años cumplía las funciones de un convento. Las beatas carmelitas, según las reglas del Manual de las beatas y hermanos terceros (1592), fueron obligadas, al igual que las monjas, al voto de la obediencia, castidad, observancia y pobreza; asumieron también el deber de oración y contemplación, obras de penitencia, ejercicio religioso y obras virtuosas, ${ }^{42}$ adoptando una vida de imita-

\footnotetext{
40 SANTANDER 1805: 375-377.

${ }^{41}$ Regla y Constituciones 1864.

${ }^{42}$ Martínez de Coria Maldonado 1592: f.82 r.-f. 105 v.
} 
ción de Cristo, el cual es uno de los efectos de la contrarreforma y del cambio del modelo de religiosidad.

Como factor importante podemos destacar la corriente espiritual denominada Devotio Moderna, impulsado por Gerardo Groote desde los Países Bajos en la segunda mitad del siglo XIV, pero que tuvo un mayor desarrolló en épocas posteriores, el objetivo de esta corriente fue "romper con la tradición escolástica y la mística especulativa centrándose en describir las experiencias de lo divino en el alma, en el lugar de meditar sobre el ser de Dios.” ${ }^{43}$

La vocación a seguir el ejemplo de Cristo lo encontramos en los escritos de varios autores cristianos. Uno de los tratados más importantes fue "De la imitación de Cristo", atribuido a Tomas de Kempis y creado antes del año de 1427:44 "Toma, pues, tu cruz, y sigue a Jesús, e irás a la vida eterna. El vino primero, y llevó su cruz y murió en la cruz por ti." ${ }^{45}$ Este tratado fue una lectura obligatoria en la época moderna y muy conocido entre personalidades eclesiásticas importantes como San Francisco de Sales, San Carlos Borromeo, Ignacio de Loyola o San Juan de la Cruz. ${ }^{46}$

Cada hombre cristiano constituye una parte de Cristo, accede a la Iglesia por medio del bautismo y después participa de su muerte a través de la eucaristía. Pero como escribe Santiago Sebastián: "el bautismo es la puerta de la Iglesia, más la profesión religiosa presenta al hombre ante la segunda puerta: la de penitencia posbautismal, que se pone en práctica por la disciplina monacal llevada con espíritu de mortificación de la carne." ${ }^{27}$ Las beatas pretendiendo ser monjas, como religiosas tenían la obligación de sacrificar su vida entera hacia Cristo, esta idea se mantuvo durante el siglo XIX y aún continúa siendo uno de los fundamentos de la vida monástica contemporánea. Queremos terminar este artículo con la cita del Espejo manual para religiosas, así novicias como profesas (1823):

Monja no mortificada, Quejona, ó poco sufrida, Es monja toda su vida, Pero monja relajada.

\footnotetext{
43 Soriano Tiguero 1998: 111.

${ }^{44}$ KubiaK 2011: 102.

45 De Kempis 1817 [antes del 1427]: 154.

46 KubiaK 2011: 103-104.

47 Sebastián 1994: 332.
} 
Tu genio lo has de vencer, Los demás has de sufrir, Si con paz quieres vivir, Y á tu Esposo complacer. ${ }^{48}$

\section{ApÉndice I}

\section{Cartelas de Silencio}

a. Cartela junto a la filacteria "Silencio"

Hermana

Si quieres por esta puerta entrar à gosar del Cielo con devoción, y reselo calla mira, y esta alerta la casa de Dios, es de oración en ella silencio todo instante el Señor te mira constante y puede castigar, tu indevoción.

b. Cartela del extremo izquierdo del centro del cuadro:

Hermana

En el coro aciste atenta ora frecuente, y devota dichos cuidados remota de tus desdichas contenta Con pausa, atención, y devocion resa el oficio parbo, diligente considera a Dios presente teme su sebera indignacion confiesate à repentida preparate fervorosa recibe à Christo amorosa recojete agradecida Deja en la puerta tu loca fantacia y todos tus banos pensamientos pues ves que ya por momentos senos ba llegando el día muriendo ban à profia la Jubentud y bejes $y$ en $t[\ldots] n[\ldots]$ alides 
a isor [...n bastantes

o que puedes morir antes

que de este coro te levantes

\title{
APÉNDICE II
}

\section{Cartelas de La monja crucificada}

a. Cartel del extremo izquierdo de la mitad superior del cuadro:

\author{
Hermana \\ Cilencio, humildad y obediencia, publica[s] \\ mis lavios con serradura y mis ojos que \\ ven[d]ados reparas, el alma mantienen pura \\ Tu Religion será bana \\ Si lo [...]que no refrenas \\ di callando a Dios tus penas \\ que Dios callando las sana \\ [...]quenta de ti a la Prelada \\ al confesor tu secreto \\ [hará] o todos con respeto \\ mirate ya amortajada. \\ A tu superior perdida \\ Veen tu hermana oficiosa \\ de sus bienes cuidadosa \\ de sus males condolida \\ de tus constituciones observan \\ en la obediencia la primera \\ para honores la postura \\ para las cargas constante.
}

b. Cartel del extremo derecho de la mitad superior del cuadro:

Hermana

La antorcha en mi diestra lla

ma, de la Caridad símbolo es y de la si

niestra la diciplina penitencia sellama

Con tus hermanas, efable

Con las seglaras, entera

Para ningun, grosera

Y para todas, tratable.

Con quien te injuria, clemente

En tus honores, confundida

Si te reprehenden, sufrida

Si tu reprendes prudente 
Con los hombres sebera

En tu trato recatada

En el cilencio estremada

En el hablas, sircunspxta

c. Cartel del extremo derecho de la mitad inferior del cuadro:

Hermana

El mundo y la muerte, que hollando meves

del primero renuncia es, y del segundo recuer.

do fuerte

En tu livertad cautiva

De tu fin insierto, sierta

Vive, viva, como muerta

Hasta que muerta estes viva.

Religiosa Mosa o bieja

A estres do la vida calma

\section{ApÉNDICE III}

Espejo de perfección Religiosa, para que la Esposa de Christo se componga, conforme, a las antecedentes Doctrinas [en:] Antonio Arbiol, La religiosa instruida con la doctrina de la sagrada escritura y Santos Padres de la Iglesia Católica para todas las operaciones de su vida regular, desde que recibe el Hábito Santo hasta la hora de su muerte, Zaragoza: Herederos de Manuel Roman, Impressor de la Universidad, 1717, p. 429.

\section{Libro III. Capitulo XXIX}

Espejo de perfección

Religiosa, para que la Esposa de

Christo se componga, conforme

a las antecedentes

Doctrinas

\section{En Coro asista atenta. Ore frequente, $y$ \\ devora. De los cuydados remota. De su \\ Professión contenta. ${ }^{49}$}

${ }^{49}$ Con la fuente negrita hemos destacado los fragmentos del texto que se encuentran en las inscripciones del cuadro. 
Confissese arrepentida. Preparese fervorosa. Reciba à Christo amorosa. Frequenrele agradecida.

Ame à Dios perseverante. Y sirvale diligente. Considerele presente. Deseele como amante.

En santa licion versada. Viva siempre compungida. En su Celda recogida. O jusamente ocupada.

Por el Convento modesta. La vista mortificada. Al mundo crucificada. $\mathrm{Y}$ en todo lugar honsta.

De tus Leyes observante. En la obediencia primera. Para los Cargos postrera. Para las cargas costante.

Comunique à su Prelada: $Y$ al Confessor su secrero. Trate à todas con respeto. Mirese amortajada.

A su Prelado rendida. Con su proximo oficiosa: De sus bienes cuydadosa: De sus males condolida.

En la salud penitente. En lo adverso resignada. En Refectorio templada. En Capitulo paciente.

De la Pobreza zelosa. Para los Pobres no esquíva. Con enfermas compassiva. Con su cuerpo rigurosa.

Con Religiosas amable: $Y$ con Seglares entera. Para ningno grosera. $Y$ para todos afable.

En la Caridad perfecta. En la humildad bien fundada. En el silencio estremada. En el hablar circunspecta. 


\section{Con quien te injuria clemente. En las}

honras confundida. Si la reprehenden sufrida. Si respondiere, prudente.

En las rexas violentada. Por obediencia, gustosa. Acuerdese que es Esposa. A Christo ya consagrada.

\section{Para los hombres severa: De su trato re-} tirada. De Sabios aconsejada. De ignorantes consejera.

\section{En su libertad, cautiva. Y de su fin cierto cierta. Viva en vida como muerta. Hasta que muerta esta viva.}

Si de Christo, y su consejo: Quisiere alcançar la palma. Componga su cuerpo, y Alma: la visa de este Espejo. Amen.

\section{BibliografíA}

\section{Fuentes manuscritas}

Archivo Arzobispal del Cusco (AAC)

AAC, Época colonial, Bienes, Signatura C8, 1, 9, Expediente sobre que el Padre Fray Pedro Lazarte Religioso comverso de San Agustin entregó la cañería, y Agua en el Beaterio de San Blas dentro de dos meses contados desde oy 17 de Noviembre de 1795, ff. 10.

AAC, Época Colonial, Órdenes religiosas, Signatura XLIV, 3, 44; Demanda de María Nicolasa de Christo, Preposita del Beaterio de Nuestra Señora del Carmen, pidiendo que su beaterio no sea convertido en capellanía, 1772, ff. 20.

AAC, Época colonial, Órdenes religiosas, Signatura C6, 3, 41, La Madre Preposita del Beaterio de San Blas sobre que sele conceda Liz.[enci] al Mayordomo de la Cofradia de la Purissima Conceps. [io] ${ }^{\mathrm{n}}$ dela Cathedral Don Christobal Mesía, para que le venda una casita, y solar contigua a su Beatrio, ff. 9.

ACC, Época colonial, Órdenes religiosas, Signatura C54, 1, 19, La demando de la madre Nicolasa de Cristo Preposita del Recogimiento de Nuestra 
Señora del Carmen al Señor Governador Provisor y Vicario general por la venta y compra de unas parcelas y casas, 1789, ff. 4.

AAC, Época Colonial, Visitas, Signatura C17, 4, 66, Razón de las Rentas de este Beaterio de S.[an] Blas del Recogim.[ien] ${ }^{\text {to }}$ de N[uest]ra. S[eno]ra del Carmen, [en:] Razón de las rentas y número de religiosas de los Recogimientos de nazarenas, el Carmen de San Blas, Beaterio de Belén, Santa Rosa, pedida por el Gobernador Eclesiástico. 1826, ff.3r.-3 v., 6 r.

\section{Archivo Regional del Cusco (ARC)}

ARC, Sección Notarial, el siglo XVII, escribano Flores Bastidas Juan, 16751680, Venta. Francisco de Madera e Ysabel Fernangil a Doña Leonarda de la Soledad, ff. 133v.-135 r.

ARC, Sección Notarial, el siglo XVIII, Melchor escribano Ayesta, 1789-1791, Escritura de Donación intervivos D.[o] ${ }^{\mathrm{n}}$ Laureano Vera y su muger D.[oñ] $]^{\mathrm{a}}$ Luiza Chacon Al Beaterio de S. $[a]^{\mathrm{n}}$ Blaz, 18 de Mayo de 1790, f. 121 v.-123 v.

ARC, Sección Notarial, el siglo XVIII, escribano Matias Ximenez Ortega, 1720, Testamento de la madre Juana de San Pedro, ff. 345 r.-347v.

\section{Fuentes impresas}

AlCIATI 1564 - A. Alciati, Iureconsulti tractatus de praesumptionibus cum Annotationibus, \& Argumentis Io.Nicolai Arelatani, Venetiis, 1564.

Arbiol 1717 - A. Arbiol, La religiosa instruida con la doctrina de la sagrada escritura y Santos Padres de la Iglesia Católica para todas las operaciones de su vida regular, desde que recibe el Hábito Santo hasta la hora de su muerte, Zaragoza: Herederos de Manuel Roman, Impressor de la Universidad, 1717.

Castro 1978 [1788] - I. de Castro, Relación del Cusco, (ed.) Carlos Daniel Valcárcel Esparza. Lima: Universidad Nacional Mayor de San Marcos, Dirección Universitaria de Biblioteca y Publicaciones, 1978 [1788].

Covarrubias Horozco 1610 - S. de Covarrubias Orozco, Emblemas morales, Madrid: Luis Sanchez, 1610.

Cuzco 16891982 [1689] - Cuzco 1689: documentos, ed. Horacio Villanueva Urteaga, Cuzco: Centro de Estudios Rurales Andinos Bartolomé de Las Casas, 1982 [1689].

De Kempis 1817 [antes del 1427] - T. de Kempis, De la Imitación de Cristo o Menosprecio del Mundo, Madrid: Edición la viuda de Barca López, 1817 [antes del 1427]. 
Diccionario 1726 - Diccionario de la lengua castellana, en que se explica el verdadero sentido de las voces, su naturaleza y calidad, con las phrases o modos de hablar. Los proverbios o refrenes, y otras cosas convenientes al uso de la lengua [...] Compuesto por la Real Academia Española, vol. 1, Madrid: Imprenta de Francisco del Hierro, 1726.

Espejo 1823 - Espejo manual para religiosas, así novicias como profesas, Barcelona: En la Imprenta de Bausi, 1823.

EsPINOZA 1804 [1799] - M. de Espinoza, La religiosa mortificada. Explicación del cuadro que la presenta con sus inscripciones tomadas de la sagrada escritura á que se añade el manual de del alma religiosa, Madrid: Imprenta Real, 1804 [1799].

Horozco y Covarrubias 1591 - J. de Horozco y Covarrubias, Emblemas morales, Segouia: Impresso por Iuan de la Cuesta, 1591.

Martínez de Coria Maldonado 1592 - D. Martínez de Coria Maldonado, Manual de las Beatas y Hermanos terceros, de la horden de la siempre Virgen, y Madre de Dios, Sancta Maria del monte Carmelo, Sevi1la: Fernando de Lara, 1592.

RIPA 1645 - C. Ripa, Iconologia di Cesare Ripa Perugino, Venetia: Presso Cristoforo Tomasino, 1645.

Regla de San Agustín 1720 - Regla de San Agustín, Constituciones, votos y estado perfección que profesan las Religiosas del Patriarca de Santo Domingo, Valencia: Antonio Balle, 1720.

Regla y Constituciones 1864 - Regla y Constituciones del Sagrado Orden de Predicadores para las religiosas de coro, Madrid: Imprenta de D. Eusebio Aguado - Pontejos, 1864.

SANTANDER 1805 - M. de Santander, Cartas familiares y algunos otros opúsculos en prosa y verso del Ilustrísimo Sr. D. Fr. Miguel de Santander, del Consejo de S. M. Obispo Amizonense, Auxiliar, Gobernador y Visitador General del Arzobispado de Zaragoza, Madrid: La imprenta de Don Benito Cano, 1805.

Tellado 1787 [1725] - B. Tellado, Nuevo manogito de flores, en tres ramilletas, compuesto de varias flores para todas personas católicas, Eclesiásticas y Religiosas, Madrid: En la Imprenta de Benito Cano, 1787 [1725].

Thомás 1768 - Á. Thomás, Compendio histórico chronológico de la fundación maravillosa del Monasterio de Jesús María de capuchinas mínimas del desierto de Penitencia de la Ciudad de Granada, Madrid: Imprenta de la viuda de Manuel Fernandez, 1768. 


\section{Fuentes secundarias}

Aguilar Piñal 1995 - F. Aguilar Piñal, Bibliografía de autores españoles del siglo XVIII, vol. 8, T-Z, Madrid: Consejo Superior de Investigaciones Científicas, 1995.

Barlés, Calvo Ruata 2001 - E. Barlés, José Ignacio Calvo Ruata, La Cartuja de Nuestra Señora de la Fuentes, "Trébede”, núm. 51 (2002), pp. $19-28$.

Braguier 2019 - L. Braguier, Servantes de Dieu. Les beatas de la couronne de Castille (1450 - 1600), Rennes: Université Rennes 2, 2019.

BuRns 2002 - K. J. Burns, Beatas, "decencia" y poder: la formación de una elite indigena en el Cuzco colonial, en: J.-J. Decoster (ed.), Incas e indios cristianos Elites indígenas e identidades cristianas en los Andes coloniales, Lima: Institut français d'études andines, Centro de Estudios Regionales Andinos Bartolomé de Las Casas, 2002, pp. 85-94.

Cantuarias Vargas 2002 - R. Cantuarias Vargas, Beaterios y monjios en el Perú virreinal, "BIRA", no 29 (2002), pp. 65-79.

Cautinho de Carvalho Rangel 2018 - L. de Cautinho de Carvalho Rangel, Esposas de Cristo: santidad e fingimento no Portugal seiscentista, Tese apresentada ao Programa de Pós-Graduação em História, Faculdade de Filosofia e Ciências Humanas da Universidade Federal da Bahia, como requisito parcial para a obtenção do grau de Doutor em História, orien. L. Bellini, coord. P. Vilas Boas Tavares, Salvador da Bahia, 2018.

Comadrán RuIz 1961 - J. Comadrán Ruiz, Bibliotecas cuyanas del siglo XVIII, Mendoza: Universidad Nacional de Cuyo, 1961.

Cos 2014 - J. de Cos, Antigua espiritualidad, liturgia y observancia de las monjas dominicas. Constituciones de 1259 y cuatro apéndices de los siglos XVI y XVIII, Fanjeaux: Hermanas Historiadoras de la Orden de Predicadores, 2014.

Cruz González 2017 - C. Cruz González, Beyond the Bride of Christ: The Crucified Abbess in Mexico and Spain, "The Art Bulletin", (4) 99 (2017), pp. 102-132.

KubiaK 2011 - E. Kubiak, La cruz como el Camino hacia la Eterna Salvación. El análisis de "Cristo llevando la cruz" del convento de Santa Teresa en Potosí (Bolivia) sobre el fondo de otras interpretaciones del tema en la misma época, en: U. Ługowska (ed.), Estudios de historia, religión y arte de España y América Latina, Varsovia: Universidad de Varsovia, 2011, pp. 100-109. 
Kubiak 2020 - E. Kubiak, El Beaterio de Nuestra Señora del Carmen a la luz del documento inédito de 1772 y la arquitectura actual del recogimiento, [en prensa].

LLOMPART 1973 - G. Llompart, El fresco de la religiosa crucificada de las Descalzas Reales de Madrid, "Traza y Baza", núm. 3 (1973), pp. 53-60.

MoISON-JABŁOŃSKA 2002 - K. Moison-Jabłońska, Obrazowanie walki dobra ze złem, Kraków: Universitas, 2002.

Nogar 2018 - A. M. Nogar, Quill and Cross in the Borderlands. Sor Maria de Ágreda and Lady in Blue. 1628 to the present, Notre Dame, Indiana: University of Notre Dame Press, 2018.

Peña Martín 2013 - Á. Peña Martín, Estoy crucificada con Cristo: en torno a la representación de la Religiosa mortificada del Monasterio de la Concepción de Riobamba (Ecuador), en: C. López Calderón, M. de los Ángeles, F. Valle, I. Rodríguez Moya (coords.), Barroco iberoamericano: identidades culturales de un imperio, vol. 1, Santiago de Compostela: Andavira, 2013, pp. 181-197.

Pi Corrales 1998 - M. de Pazzis Pi Corrales, Tercera Orden, en: E. Martínez Ruiz (ed.), Diccionario de historia moderna de España, vol. I, La Iglesia, Madrid: Ediciones Istmo, 1998, pp. 255-256.

SAlazAr Simarro 2011 - N. Slazar Simarro, El papel del cuerpo en un grabado del siglo XVIII, en: A. Rubial García, D. Biñko de Peralta (eds.), Cuerpo y religión en el México Barroco, México: Escuela Nacional de Antropología e Historia, Instituto Nacional de Antropología e Historia, Consejo Nacional para la Cultura y las Artes, 2011, pp. 109143.

SEbAStián 1993 [1985] - S. Sebastián, Alciato. Emblemas, Madrid: Akal, 1993 [1985].

Sebastián 1994 - S. Sebastián, El alma mortificada, en: C. Barrón (ed.), Juegos de ingenio y agudeza. La pintura emblemática de la Nueva España, México: Instituto Nacional de bellas Artes, Museo Nacional de Arte, 1994, pp. 332-333.

SeEвoнm 1996 - A. Seebohm, The Crucified Monk, "Journal of the Warburg and Courtauld Institute, vol. 59 (1996), pp. 61-102.

Soriano Tiguero 1998 - C. Soriano Tiguero, Devotio Moderna, en: E. Martínez Ruiz (ed.), Diccionario de historia moderna de España, vol. I, La Iglesia, Madrid: Ediciones Istmo, 1998, pp. 111-112.

Vistarini, Cull 1999 - A. Bernat Vistarini, John T. Cull, Enciclopedia de emblemas españoles ilustrados, Madrid: Akal, 1999. 


\section{Summary}

Symbolic death. Painting presenting allegory of Silence and Crucified Nun from Beaterium of Our Lady of Mount Carmel in St. Blaise Parish in Cusco

The article presents a painting which has never been reproduced or publicly displayed before. The work comes from the Beaterium of Our Lady of Mount Carmel in St. Blaise Parish in Cusco. It is a two-sided representation. The obverse side contains a figure of a nun in a Carmelite habit, who puts his hand to his mouth and orders silence, which is communicated not only by the gesture, but also by the inscription accompanying the representation. On the reverse side we can see an image of a crucified nun. The painting used to function as a door leading to the novitiate, which could be established based on the archival photo. The article describes iconography of the work, as well as the sources for most of the inscriptions that accompany the images. The painting is presented in a broader historical and cultural context of Cusco Beaterium functioning.

Keywords: crucified nun, modern iconography, female monasteries, Cusco

\section{Streszczenie}

Symboliczna śmierć. Obraz z przedstawieniem alegorii Ciszy i Ukrzyżowanej zakonnicy $\mathrm{z}$ beaterium pod wezwaniem Matki Boskiej Szkaplerznej (Beaterio del Carmen) w parafii św. Błażeja w Cusco

W artykule został zaprezentowany obraz, który nigdy wcześniej nie był reprodukowany ani eksponowany publicznie. Dzieło pochodzi z beaterium pod wezwaniem Matki Boskiej Szkaplerznej w parafii św. Błażeja w Cusco. Jest to przedstawienie dwustronne, na awersie znajduje się postać zakonnicy w habicie karmelitańskim, która przykłada rękę do ust i nakazuje ciszę, o czym informuje nas, prócz gestu, towarzysząca przedstawieniu inskrypcja. Na rewersie zaś zobaczyć można wizerunek ukrzyżowanej mniszki. Malowidło funkcjonowało niegdyś jako drzwi prowadzące do nowicjatu, co możliwe było do ustalenia dzięki odnalezieniu archiwalnej fotografii. W artykule scharakteryzowana została ikonografia dzieła, a także udało się wskazać źródła dla większości inskrypcji, które towarzyszą wyobrażeniom malarskim. Obraz został zaprezentowany w szerszym kontekście historycznym i kulturowym funkcjonowania kuskeńskiego beaterium.

Słowa kluczowe: ukrzyżowana zakonnica, ikonografia nowożytna, klasztory żeńskie, Cusco 